\title{
Puheenvuoro kansallisesta avoimen tieteen uudesta seurantamallista vastuullisen arvioinnin ja yliopiston näkökulmasta
}

\author{
Laura Himanen \\ Tampereen yliopisto \\ laura.himanen@tuni.fi \\ https://orcid.org/0000-0001-8289-9766
}

Susanna Nykyri
Tampereen yliopisto
susanna.nykyri@tuni.fi
https://orcid.org/0000-0002-5018-5176

A new model for monitoring open science was sent for community consultation this Autumn. It is planned to be used for the first time in early 2022. In this article we discuss how the proposed model resonates with principles of responsible research evaluation using the SCOPE framework. We conclude that even though it is important to monitor the developments in open science on national level, the new model creates a ranking by making comparisons between organisations possible. This can cause optimization as universities try to secure a winning position, which is anticipated to result in unintended consequences. We call for more time for universities to implement all the recommendations already published. Also, we feel there is still a lot to do on the national level so before focusing on universities' maturity in open science, the focus should be on making sure the national environment for open science is more complete.

Asiasanat: arviointi, kehittäminen, avoin tiede, seuranta, vastuullisuus, SCOPE 


\section{Johdanto}

Suomessa on ollut selkeä kansallinen tahtotila kehittää avointa tiedettä niin sen tahtotilan, toimintaedellytysten kuin toteumienkin tasolla. Kansainvälisesti vertailtuna Suomi näyttäytyy pyrkimyksissään ja kehittämistoimissaan kunnianhimoisena (ks. esim. Landscape of EOSC-related infrastructures and initiatives 2020). Yhdeksi avoimen tieteen edistämiselle asetettujen tavoitteiden toteutumisen edellytykseksi on esitetty sen kehityksen seuranta kansallisesti ja organisaatioiden tasolla. Avoimen tieteen ja tutkimuksen kansallinen ohjausryhmä asetti vuonna 2020 työryhmän kehittämään avoimen tieteen seuraavan sukupolven seurantamallia, ja tämä uusi seurantamalli avattiin tutkimusyhteisölle laajaa ja avointa kommentointia varten 27.9.-1.11.2021. Kommentoitavana olivat seurantamalliluonnos, seurannan kyselyn ja sen pisteytyksen luonnos ja avoimen julkaisemisen kokonaiskustannusten luonnos. (TSV 2021a, 2021b, 2021c) Uusi malli oli kommentointivaiheessa esitetty vahvistettavan vuoden 2021 loppuun mennessä ja toteutettavan 2022 niin, että tulokset ovat julkaistavissa lokakuussa 2022. Tässä artikkelissa keskitymme tarkastelemaan seurantamallia ja seurannan luonnoksessa ehdotettua toteutustapaa vastuullisen arvioinnin näkökulmasta ja rajaamme tarkastelun yliopistonäkökulmaan.

Kansallisesti avoimen tieteen kehitystä mm. tutkimusorganisaatioissa on seurattu opetus- ja kulttuuriministeriön (OKM) toimesta jo vuodesta 2015. Viimeisin kansallinen seuranta on toteutettu 2019 ja julkaistu 2020 (ks. Forsström, Lilja \& Alamantila 2020). Tällöin todettiin, että kansallisella tasolla tahtotila tutkimusorganisaatioissa on jo erittäin korkealla ja on ajankohtaista edistää systemaattista jatkokehittämistä. Yliopistoista peräti yhdeksän ja ammattikorkeakouluista seitsemän sijoittui korkeimmalle kypsyystasolle. (emt., OKM 2020). Samaan aikaan useassa yhteydessä keskusteltiin, että seurantaindikaattorit eivät ole aivan ajantasaiset suhteessa avoimen tieteen laajeneviin tavoitteisiin ja nykyiseen kehitystilaan. Uuden seurantamallin on tarkoitus täyttää tämä puute ja sen päivittämistä tehdään Tieteellisten seurain valtuuskunnalle (TSV) osoitetun kansallisen avoimen tieteen koordinaation piirissä (TSV 2020). 


\section{Uusi seurantamalli}

Uudessa seurantamallissa (TSV 2021a ja 2021b) avoin tiede nähdään aiempaa laajemmin ja se heijastaa kansallisen avoimen tieteen koordinaation piirissä olevaa asiantuntijatyön jakoa sekä pohjautuu pitkälti jo valmistuneisiin avoimen tieteen eri osa-alueiden päämääriä ja toimenpiteitä esitteleviin linjauksiin ja osalinjauksiin. Tiedonkeruumenetelmät ovat kysely ja ennakkoon määriteltyjen eri portaalien kautta saatavat tiedot ja toteumien lukemat. Tulevan avoimen tieteen seurannassa tutkimusorganisaatioiden arvioitavat avoimen tieteen osa-alueet ovat: 1) organisaatioiden avoimen tieteen ohjausmekanismit/ dokumentit; 2) organisaation tekemä kansallinen ja kansainvälinen yhteistyö avoimen tieteen edistämiseksi; 3) toimintakulttuurin avoimuus; 4) julkaisuiden avoimuus; 5) aineistojen ja infrastruktuurien avoimuus sekä 6) oppimisen avoimuus.

Toimintakulttuurin avoimuuden alla arvioitavana ovat kannustimet ja arviointi, kannustimien ja arvioinnin palvelut sekä kansalaistiede. Viimeksi mainitussa keskiössä ovat kansalaistieteen mahdollistavien palveluiden saatavuus. (emt.) Kansalaistieteen nostaminen yhdeksi seurannan systemaattisesti kehitettävistä kohteista on uusi avaus suomalaisten tutkimusorganisaatioiden toiminnan tarkastelussa. Kansalaistiede on huomioitu myös tuoreessa UNESCOn (2021) avoimen tieteen suosituksessa, jossa kansalaistieteen (citizen and participatory science) sisällyttämisen edistämisen katsotaan olevan kiinteä osa niin kansallisen, organisatorisen kuin rahoittajien tason avoimen tieteen politiikkaa ja käytänteitä.

Julkaisuiden avoimuuden tarkastelussa huomio on mm. OKM:n vertaisarvioitujen julkaisuiden avoimuuskertoimella kannustamista laajempi ja ottaa huomioon muutkin kuin vertaisarvioidut julkaisutyypit. Tulevaisuuden näkyminä ja ehdotettuja kehitettäviä indikaattoreita ovat avoin vertaisarviointi (esim. avoimeen vertaisarviointiin osallistuneet tutkijat, avoimesti vertaisarvioidut julkaisut, avointa vertaisarviointia hyödyntävät kotimaiset julkaisukanavat) ja ennakkojulkaisujen (pre-print) määrä ja käyttö. (emt.)

Opinnäytetöiden avoimuuden määrällinen seuranta on ajateltu toteutettavan 2024, ja tällöin tarkastelukohteina olisivat avoimesti saatavat opinnäytetyöt ja siinä käytetyt tietolähteet tutkimusorganisaatioiden ovat julkaisuarkistot, Theseus ja opintotietojärjestelmät (emt.). Sinänsä opinnäytteiden avoimuus on jo laissa turvattu ja ne ovat julkisia asiakirjoja. Julkaisuarkistojen kattavuuden varmistaminen myös opinnäytetöiden osalta on omiaan lisäämään tasapuolista välitöntä saatavuutta.

Julkaisupalveluiden avoimuutta suunnitellaan tarkasteltavan kyselyllä ja siinä kerättävät organisaation tasomäärittelyyn vaikuttavat keskeiset indi- 
kaattorit kohdistuvat keinoihin, joilla varmistetaan palveluiden tasapuolinen saatavuus, palveluiden kirjoon ja avoimen julkaisemisen kannusteisiin sekä arviointiin. (emt.)

Tutkimusaineistojen ja infrastruktuurien avoimuuden seurannassa katsotaan, että sen tulee kannustaa hyvään ja vastuulliseen aineistonhallintaan sekä monipuoliseen menetelmähallintaan. Organisaatioiden tasomäärittelyyn käytettävät määrälliset indikaattorit aineistojen avoimen saatavuuden seuraamiselle vuonna 2022 kohdistuvat siihen, tarjoaako organisaatio aineistonhallintaan työkalun kaikille tutkijoille. Vuoden 2024 indikaattoreita on tarkoitus käyttää jo laajemmin, niiden kattaessa metatiedot (aineistoilla avoimesti saatavilla oleva metadata Metaxissa) sekä avointen aineistojen/ datasettien määrä metatietojen perusteella tai avointen materiaalien lataukset, uudelleenkäyttö (julkaisuissa) ja viittaukset (tietolähteenä Metax). Kansallisen avoimuuden kehittymisen indikaattori vuonna 2022 on pitkäaikaissäilytys eli CSC:n PAS-palveluun tai organisaation omaan palveluun siirrettyjen tietoaineistojen ja julkaisujen määrä sekä niiden prosenttiosuudet kaikista tietoaineistoista ja julkaisuista. Käytettyinä tietolähteinä esitetään PAS-palvelu ja Metax. Tulevaisuuden näkyminä ja ehdotettuina kehitettävinä indikaattoreina esitetään DMP-seuranta: DMP-määrät, niiden arviointi organisaatioissa; FAIR-periaatteiden noudattaminen; menetelmien ja ohjelmistojen avoimuuden seuranta; esirekisteröintien seuranta; kuvailevan metadatan avoimuus; ja linkitetty data ja/tai PID-graph. (emt.)

Infrastruktuurien avoimuuden seurannassa keskitytään suomalaisten tutkimusorganisaatioiden hallinnoimien infrastruktuurien avoimuuteen. Määrällisenä indikaattorina suunnitellaan vuoden 2024 arviointiin sisältyvän tutkimusinfrastruktuurien ja käyttöpolitiikkojen näkyvyys tutkimustietovarannossa. Tulevaisuuden näkyminä ja ehdotetut kehitettävät indikaattorit ovat tutkimusinfrastruktuurien käyttöasteen seuranta: viittaukset ja viittauskäytänteet, ja EOSC:ssa (European Open Science Cloud) kehitteillä olevat mittarit, standardit ja/tai suositukset sekä tietovarannot, jotka sisältävät tietoja kaiken kokoisista infrastruktuureista, annettuna esimerkkinä Open Iris. (emt.)

Uudistetussa mallissa aineistojen ja infrastruktuurien osalta toteumien seuranta painottuu siis myöhempään vaiheeseen, ja vuoden 2022 arvioinnissa suunnitellaan tarkasteltavan enemmän sitä, miten tutkimusorganisaatiot mahdollistavat palveluillaan tutkijoiden tasavertaista mahdollisuutta julkaista aineistonsa avoimesti. Vuoden 2022 seurannassa fokuksessa ovat: aineistojen avoimuuden mahdollistava koulutus; tukipalveluiden organisointi; tukipalveluiden saatavuuden tasapuolisuus; avoimien aineistojen palveluiden kattavuus; avoimien aineistojen julkaisemisen tuki ja infrastruktuurit; aineistojen 
avaamisen kannusteet; ja infrastruktuurien avaamisen palvelut ja seuranta. Käytetty tiedonkeruumenetelmä näissä on kysely. (emt.)

Avointen oppimiskäytäntöjen osalinjausta valmistellaan vuosina 2021-22, ja sen myötä keskeiset työkalut ja indikaattorit tulevat tarkentumaan. Organisaatioiden tasomäärittelyyn käytettävänä määrällisenä indikaattorina oppimateriaalien avoimen saatavuuden seuraamiselle vuonna 2024 on suunniteltu käytettävän avoimien oppimateriaalien kirjastoon tallennettujen tai linkitettyjen avoimien oppimateriaalien määrä ja tietolähteenä avointen oppimateriaalien kirjaston (aoe.fi) tiedot. Oppimisen ja oppimateriaalien avoimuuden palveluita on tarkoitus seurata jo 2022 kyselyosuudessa, ja tällöin huomio kohdentuu tutkimusorganisaatioiden tukipalveluiden organisointiin, oppimisen avoimuuden osaamisen varmistavaan koulutukseen, oppimateriaalien tekijänoikeuksiin ja lisensointiin liittyviin palveluihin, avointen oppimateriaalien löydettävyyteen, avoimien oppimateriaalien laatukriteerien soveltamiseen, avoimien oppimateriaalien saavutettavuuspalveluihin ja avoimien materiaalien hyödyntämiseen opetuksessa sekä oppimisen avoimuuteen kannustamiseen. Tulevaisuuden näkyminä ja ehdotettuina kehitettävinä indikaattoreina luonnoksessa esitetään: avoimen oppimisen laatukriteerien soveltaminen; avoimen lähdekoodin ohjelmistojen käyttö opetuksessa; oppimisympäristöjen saatavuus ja saavutettavuus; oppijoiden oppimistuotosten avoin jakaminen; avoin opetustarjonta; ja tiedeviestinnän ja tiedekasvatuksen toteuttaminen. (emt.)

Seurannan pisteytys on jo kuvattu kommentoitavassa luonnoksessa. "Seurannan indikaattorit tuottavat pisteytettävää tietoa. Indikaattorit eivät ole pisteiltään samanarvoisia, vaan pisteet määritellään jokaisen indikaattorin kohdalla erikseen. Osa indikaattoreista ei koske kaikkia organisaatiotyyppejä (esimerkiksi avoimeen oppimiseen liittyvät indikaattorit eivät koske tutkimuslaitoksia). Osassa indikaattoreista pisteytys saattaa olla suhteellinen organisaation kokoon sillä tavoin, että pienemmän organisaation on suurta helpompi saada maksimipisteet indikaattorin kohdalla. Pisteytyksen periaatteet ovat läpinäkyviä ja kaikkien saatavilla.” Seurannan tulokset on tarkoitus esittää niin, että se mahdollistaa avoimen tieteen eri osa-alueiden ja toimintatapojen sekä niiden välisten yhteyksien tarkastelun. (emt., ks. myös TSV2021c)

Kansallisella avoimen tieteen seurantamallilla ja sen tuloksilla on ollut tärkeä rooli ja arvo osoittamassa, mihin kunkin tutkimusorganisaation tulisi kohdentaa jatkokehittämistä. Toki se tuo esille myös eri organisaatioiden vahvuuksia. Sijoitus ei kuitenkaan ole koskaan saavutettu etu, vaan seurannassa hyvin sijoittuminen edellyttää jatkuvaa lisäkehittämistä niin avoimen tieteen tavoitteet mahdollistavien palveluiden, ohjaustapojen kuin avoimuuden toimintakulttuurin omaksumisessa. 


\section{Vastuullinen arviointi}

Tutkimuksen ja tutkijoiden arvioinnilla on merkittäviä vaikutuksia niin yksilökuin organisaatiotasolla. Erityisesti määrällisten indikaattoreiden hyödyntäminen arvioinnissa on herättänyt tiedeyhteisössä huolta, sillä huolimatta siitä, että niiden rajoitukset arvioitaessa esimerkiksi tieteellistä laatua tai vaikuttavuutta ovat hyvin tiedossa, niitä silti käytetään sekä laadun että vaikuttavuuden arviointiin (de Rijcke \& Rushfort 2015). Yhtenä vastauksena näihin huoliin tiedeyhteisö on kuluneen vuosikymmenen aikana luonut useita vastuullisen arvioinnin julistuksia tai periaatteita. Näistä tunnetuimmat lienevät DORA (San Francisco Declaration on Research Assessment, https://sfdora. org/), Leidenin manifesti (Hicks et al. 2015) ja Metric Tide (Wilsdon et. al. 2015).

Periaatteet ja julistukset tarjoavatkin hyvän lähtökohdan arvioinnin vastuullisuudelle, mutta niiden toteutuminen vaatii käytännön toimeenpanoa. Valitettavan usein vastuullisesti toteutettavan arvioinnin haasteissa on loppujen lopuksi kysymys siitä, että päädytään arvioimaan sitä, mitä voidaan (helposti) mitata. Mittaaminen ja määrälliset indikaattorit eivät kuitenkaan kata läheskään kaikkea sitä, mikä on akateemisen työn ja toiminnan laatua, joten arvioinnin tulisi lähteä siitä, mitä arvostetaan. Jotta siihen pystyttäisiin, pitäisi löytää tapoja mitata sitä, mitä arvostetaan. (Agate et al. 2020)

Nyt kommentoitavana olevan Avoimen tieteen seurantamallin lähtökohta, eli se mitä arvostetaan, on selvä: tieteen avoimuus. Ehdotuksessa myös määritellään, miten tieteen avoimuuden edistymistä voidaan mitata osin vanhoin osin tätä tarkoitusta varten kehitetyillä indikaattoreilla. Kaikella seurannalla on kuitenkin toimintaa suurestikin ohjaava merkitys. Siksi itse seurantamallia on myös erityisen tärkeä tarkastella - niin sisältöä, toimintatapaa kuin vaikutuksia. Ohjaako seuranta oikeaan suuntaan? Vastaavaa keskustelua on käyty mm. JUFOon liittyen siitä, miten luokitusta käytetään vastoin ohjeita yliopistojen sisäisessä rahanjaossa ja jopa yksittäisten tutkijoiden arvioinnissa (ks. esim. Pölönen et al. 2021).

Kansainvälinen arvioinnin työryhmä (https://inorms.net/researchevaluation-group/) tarttui muutama vuosi sitten vastuullisen arvioinnin ideaalien käytännön toimeenpanon haasteisiin ja tuotti sen tueksi viisiportaisen prosessimallin, SCOPEn (ks. esim. Himanen \& Gadd 2019). Vaiheet kuvattu tarkemmin taulukossa 1. 
Taulukko 1: SCOPE-malli.

\begin{tabular}{|l|l|}
\hline START with what you value & $\begin{array}{l}\text { Usein arvioinnissa lähdetään liikkeelle siitä, mitä } \\
\text { voidaan arvioida, eli mistä on dataa saatavilla, tai } \\
\text { siitä, mitä ulkoiset toimijat, kuten tutkimusrahoit- } \\
\text { tajat tai ministeriö tavoittelevat, ei siis siitä, mitä } \\
\text { organisaatio itse tavoittelee tai mitä se arvostaa } \\
\text { arvioinnin kohteessa. }\end{array}$ \\
\hline CONTEXT considerations & $\begin{array}{l}\text { Arviointia suunnitellessa on aina oltava selvää mitä } \\
\text { arvioidaan ja miksi. Muun muassa arvioinnin koh- } \\
\text { teen koko tai siihen kuuluvat tieteenalat asettavat } \\
\text { omat reunaehtonsa sille, miten voidaan arvioida, } \\
\text { samoin kuin arvioinnin tarkoitus. }\end{array}$ \\
\hline OPTIONS for evaluating & $\begin{array}{l}\text { Tämän vaiheen tarkoitus on kartoittaa eri arvioin- } \\
\text { timenetelmät, laadulliset ja määrälliset, jotka ovat } \\
\text { mahdollisia ja relevantteja valitun kohteen arvi- } \\
\text { ointiin. }\end{array}$ \\
\hline PROBE deeply & $\begin{array}{l}\text { Valittuja arviointimenetelmiä kannattaa tar- } \\
\text { kastella neljän kysymyksen kautta: 1. ketä/keitä } \\
\text { menetelmät saattavat syrjiä? Epäreilu asetelma } \\
\text { eri tieteenalojen välillä on tyypillinen esimerk- } \\
\text { ki tästä. 2. minkälaista pelaamista tai optimointia } \\
\text { menetelmät saattavat aiheuttaa? Sillä sitä saa, mitä } \\
\text { mittaa. 3. minkälaisia ei-toivottuja vaikutuksia } \\
\text { menetelmillä saattaa olla? Ja viimeisenä 4. mitkä } \\
\text { ovat arvioinnin kustannukset suhteessa hyötyihin? } \\
\text { Jokainen arviointi vaatii resursseja, ja vaadittavien } \\
\text { resurssien on oltava järkevissä mittasuhteissa } \\
\text { ennakoitaviin hyötyihin ja tuloksiin. }\end{array}$ \\
\hline EVALUATE your evaluation & $\begin{array}{l}\text { Kun arviointi on toteutettu, on hyvä arvioida, tuot- } \\
\text { tiko se haluttuja tuloksia. }\end{array}$ \\
\hline
\end{tabular} \mid \begin{tabular}{l}
$|c|$ \\
\hline
\end{tabular}

SCOPEn viisi vaihetta perustuvat kolmelle periaatteelle:

Arvioi vain kun se on tarpeen - arviointi ei aina ole se paras toimintamalli, joten kun esimerkiksi halutaan kannustaa johonkin toimintaan voisi olla järkevämpää panostaa sen toiminnan mahdollistamiseen ennemmin kuin arvioida sitä.

Arvioi arvioitavien kanssa - jokaisen arvioinnin suunnittelussa ja toteutuksessa pitäisi huomioida arvioinnin kohteena olevat jo alkuvaiheessa sieltä saa parhaiten tietoa niistä asioista, jotka juuri sen kohteen kannalta ovat merkittäviä ja sitä kautta hyviä arvioinnin kohteita.

Käytä asiantuntïoita! Tieteellistä tutkimusta ei voi tehdä millä tahansa osaamistaustalla, sama koskee tieteellisen tutkimuksen arviointia. 
SCOPE on tarkoitettu malliksi, jota seuraamalla mikä tahansa taho pystyy suunnittelemaan ja toteuttamaan vastuullisen arvioinnin, jonka kohteena voi olla mikä tahansa kokonaisuus. SCOPEn avulla on myös mahdollista tarkastella kuinka hyvin jo olemassa oleva arviointijärjestelmä täyttää vastuullisuuden periaatteet. Me halusimme tarkastella lausuttavaa malliversiota Avoimen tieteen seurannasta SCOPEn vaiheiden ja periaatteiden kautta ja samalla testata SCOPEa käytännössä.

\section{Avoimen tieteen seurantamalli SCOPE-linssien läpi tarkasteltuna}

Tieteen ja tutkimuksen avoimuuden arvo ei ole kenellekään epäselvä, ja siinä mielessä Avoimen tieteen seurantamalli täyttää hyvin SCOPEn ensimmäisen vaiheen kriteerin. Seurantamallin indikaattoreiden ja seurantakohteiden perustana ovat kansallisen avoimen tieteen koordinaation asiantuntijaryhmissä yhteisesti tuotetut linjaukset ja suositukset ${ }^{1}$, joten lähtökohtaisesti ne ovat yhteisesti hyväksyttyjä. Kuitenkin se, missä määrin ja missä aikataulussa avoimuuden tavoitellaan toteutuvan ja miten sen toteutumista seurataan, määritellään muualla kuin seurannan kohteina olevissa organisaatioissa, ja mikäli seurannassa halutaan pärjätä, organisaatiossa saatetaan kokea tarpeelliseksi muuttaa toimintoja ja niiden organisoimista indikaattoreiden mukaisiksi.

Toisessa vaiheessa tarkastellaan sitä, kuinka hyvin arvioinnin konteksti on selvillä, eli mitä arvioidaan ja miksi, ja minkälaisia reunaehtoja nämä asettavat käytettäville arviointimenetelmille ja aineistoille. Seurannan kohteena ovat ensi vaiheessa tutkimusta tuottavat organisaatiot (myöhemmin mukaan otetaan myös tutkimusta julkaisevat ja rahoittavat organisaatiot sekä palveluita ja infrastruktuuria toteuttavia tahoja), ja koska seuranta toteutetaan organisaatiotasolla, sanotaan siinä voitavan ottaa huomioon sekä tieteenalojen että organisaatioiden moninaisuus. Käytännössä tällä viitattaneen siihen, etteivät kaikki indikaattorit koske kaikkia organisaatioita, ja että osassa indikaattoreista pisteytys suhteutetaan organisaation kokoon. Organisaatioiden moni-

$1 \quad$ Ks. kansallisessa avoimen tieteen koordinaatiossa tuotetut

- julkaistut linjaukset https://avointiede.fi/fi/linjaukset-ja-aineistot/kotimaiset-linjaukset

- julkaistut suositukset https://avointiede.fi/fi/linjaukset-ja-aineistot/kotimaiset-suositukset

- linjausaikataulu https://avointiede.fi/fi/linjaukset-ja-aineistot/kotimaiset-linjaukset/linjausaikataulu 
naisuus tulee siis em. seikkojen osalta huomioiduksi, mutta huomattavasti hankalampi asia, eli tieteenalojen moninaisuus, ei.

Seurannan hyödyiksi, eli se miksi seuranta toteutetaan, on listattu useita. Osa hyödyistä liittyy tiedon keräämiseen avoimuuden tasosta esimerkiksi kehittämisen tueksi, mutta tuloksia voidaan käyttää myös organisaatioiden keskinäiseen vertailuun ja osana sopimusneuvotteluissa käytettävien indikaattorien valintapalettia. Kun seurantaa käytetään tiedon keräämiseen tai kehittämisen tueksi sillä on vähemmän vaikutusta seurannan kohteeseen kuin silloin, kun seurantaa käytetään esimerkiksi vertailuun ja arvottamiseen. Ja mitä enemmän seuranta vaikuttaa kohteisiinsa, sen suuremmat ovat riskitkin (liittyen esimerkiksi toiminnan optimointiin mallin ohjaamalla tavalla). Mitä suuremmat riskit, sitä tarkempi on oltava sen suhteen, miten arvioidaan ja vaikkapa mitä indikaattoreita käytetään.

Kolmannessa vaiheessa tarkastelun kohteena ovat ne menetelmät ja indikaattorit, joiden avulla seuranta toteutetaan. Seurantamallissa on selkeästi sisäistetty se, etteivät saatavilla olevat määrälliset indikaattorit riitä kattamaan keskeisiä avoimuuden osatekijöitä, ja aineistoa täydennetään merkittävin osin kyselyllä. Kysely kuitenkin toteutetaan monivalintakysymyksinä ja vastaajille on alusta asti selvää, miten vastaukset pisteytetään. Toisin sanoen, vaikka kyselyn tarkoitus on täydentää määrällistä aineistoa laadullisella, laadullista tietoa organisaation linjauksista, toimenpiteistä ja toiminnan organisoimisesta mitataan kyllä/ei -vastauksilla ja vastausten pisteytys luo mittariston toiminnan laadun arvioinnille. Voidaan jopa ajatella, että kaikki hyväksytyt tavat edistää avoimuutta on sisällytetty monivalintavastauksiin, eikä organisaatiolle ole seurannan näkökulmasta palkitsevaa toimia eri tavalla, mikäli haluaa pärjätä seurannassa. Monivalintakysymyksillä ehkä minimoidaan avointen vastausten tulkinnanvaraisuus ja varmasti helpotetaan seurannan aiheuttamaa työkuormaa organisaatioissa, mutta samalla saatetaan vähentää organisaatioiden motivaatiota kehittää luovasti itselleen parhaita tapoja edistää avoimuutta.

Neljännessä vaiheessa keskitytään tarkemmin siihen, minkälaisia vaikutuksia seurannalla voi olla ja toisaalta mikä on sen hyöty suhteessa sen aiheuttamiin kustannuksiin. Luonnollisesti seurannan vaikutuksia voi täysin arvioida vasta kun se on toteutettu, mutta joitain pohdintoja voidaan kenties tehdä ennakoidenkin.

Seurantamallin kyselyn hyödyntäminen organisaatioiden itsearvioinnin välineenä ja toiminnan kehittämisen tukena vaikuttaa kannatettavalta. Huolta herättää kuitenkin seurantamalliin sisällytetty varsin seikkaperäinen vertailumahdollisuus, eli pisteytys, joka arvottaa organisaatioiden toimintatavat suhteessa toisiinsa. Kuten seurantamallissa mainitaan, seuraamisella 
vaikutetaan suoraan ja välillisesti siihen, miten organisaatioiden kehittämistyötä ja käytänteitä painotetaan, mikä haastaa organisaatioiden oman harkintavallan käyttöä, ja saattaa jopa vähentää organisaatioiden herkkyyttä kehittää ominaispiirteitään lähemmin tavoittavia seurantaindikaattoreita. Pisteytys määrittää mitä pitäisi tehdä ja miten. Toisaalta voidaan ajatella, että avoimen tieteen edistäminen suomalaisessa tutkimusyhteisössä vaatii selkeitä toimintaohjeita, jolloin haluttu tulos pyhittää keinot. Olemmeko siis aivan varmoja siitä, että seurantamalliin valikoituneet keinot ovat ne ainoat oikeat tai parhaimmat? Ja toisaalta, onko vastausten pisteytys kyllin suhteessa toisiinsa (sekä yksittäisten osa-alueiden tai edistämisen tapojen sisällä että niiden välillä) ja kunnioittaako pisteytys eri organisaatioiden strategisestikin valittuja painopisteitä? Miten helppoa on muuttaa seurannan painopisteitä, jos jo käynnistetty malli ei näyttäydy vaikutuksiltaan ja/tai sisällöiltään toimivalta ja esitetään kuitenkin koko tutkimusyhteisön luomuksena?

SCOPEn viimeisessä vaiheessa kehotetaan arvioimaan toteutettu arviointi. Seurantamallia on tarkoitus kehittää jatkuvasti ja sen indikaattoreita seurataan ja arvioidaan sekä muutetaan jos se on tarpeen. Malli siis kehittyy kokemusten karttuessa, mikä onkin ensiarvoisen tärkeää. Avoimen tieteen kehitys on nopeaa, ja yhtenä vuotena kerättyä aineistoa ei välttämättä ole enää kaikilta osin relevanttia kerätä yhdenmukaisena seuraavana vuonna. Toisaalta seurannassa käytettävät indikaattorit on tarkoitus julkaista aina 18 kuukautta ennen seuraava seurantakierrosta, ja ottaen huomioon jo mainittu avoimen tieteen nopea kehitys, on mahdollista, että näin pitkään tiedossa olevat indikaattorit rajaavat kehittämistyötä organisaatioiden optimoidessa tulevaa sijoittumistaan ja siten voivat jopa aiheuttaa jälkeen jäämistä suhteessa kansainväliseen kehitykseen.

\section{Johtopäätökset}

Avoimen tieteen seurantamallin luonnos toteuttaa nähdäksemme hyvin suurelta osin vastuullisen arvioinnin periaatteita. Seurannassa avoin tiede ymmärretään laajasti ja siinä pyritään tarkastelemaan avointa tiedettä kokonaisuutena, eikä tyydytä seuraamaan sen edistymistä vain jo tarjolla olevien indikaattoreiden valossa. Kun seurannan kohteena ovat tutkimusorganisaatiot, vastuuta avoimen tieteen edistämisestä ja toteutumisesta ei sälytetä yksittäisille tutkijoille. Malli kiinnittää huomion ennemminkin niihin keinoihin, joilla organisaatiot voivat tukea ja mahdollistaa avoimen tieteen toteutumista. Seurannassa käytettävät kriteerit ja indikaattorit ovat tiedossa etukäteen ja vastausten pisteytys on avoimesti esillä jo vastatessa kyselyyn. 
Lisäksi seurannassa otetaan huomioon seurattavien organisaatioiden moninaisuus siten, että organisaation toiminnan näkökulmasta epärelevantteja indikaattoreita ei käytetä ja osa indikaattoreista suhteutetaan organisaation kokoon vähentäen näin epäreiluja asetelmia pienten ja suurten organisaatioiden välillä. Seurantamallin suunnittelu on tehty sen kohteiden kanssa yhteistyössä (vrt. SCOPEn periaate "arvioi arvioitavien kanssa”), ja siinä on hyödynnetty vahvasti asiantuntijuutta (vrt. SCOPEn periaate "käytä asiantuntijoita”). Kohteenahan ovat organisaatioiden ohjaavat dokumentit, palvelut ja yhteistyö, ja linjauksia tuottavat asiantuntijaryhmät koostuvat laajasti eri tutkimusorganisaatioiden asiantuntijoista. Seurantamalliluonnoksen avoin kommentointi onkin nähdäksemme paras käytettävissä oleva tapa seurannan kohteiden osallistua seurantamallin muotoutumiseen. Haasteena on kuitenkin alusta alkaen ollut tutkijayhteisön vähäinen osallistuminen linjaustyöhön, joten on mahdollista, että asiantuntijaryhmät eivät ole pystyneet kattamaan linjauksissa kaikkia tutkijan näkökulmasta merkittävimpiä tapoja edistää avoimuutta. Mikäli tutkijoiden näkökulmaa ei saada mukaan linjaus- ja suositustyöhön, uhkaavat ne jäädä tutkijoille vieraaksi ja toisaalta linjausten vaatimukset saatetaan kokea merkityksettömänä lisätyönä, jota tehdään jo nyt liian pienillä resursseilla (ks. Lilja 2020; Lahtinen 2021).

On ilmeistä, että asetettujen tavoitteiden toteutumista tulee seurata (vrt. SCOPEn periaate "arvioi vain kun se on tarpeen”). Voisi kuitenkin olla hyvä miettiä vielä sitä, missä vaiheessa seuranta tässä mittakaavassa ja seikkaperäisyydessä toteutetaan. Pidämme myönteisenä, että uusi seurantamalliluonnos kattaa kaikki tunnistetut keskeiset avoimen tieteen osa-alueet, haastavuus ilmenee siis seurantamallin indikaattoritasolla. Suurin osa linjauksista, joihin seurantamallin indikaattorit perustuvat, ovat tuoreita ja moni sinänsä nyt jo tunnistettua tarvetta palveleva keskeinen osalinjaus peräti vielä laadintavaiheessa, eikä niiden sisältämiä toimenpiteitä ole ehditty jalkauttamaan organisaatioihin.

Mitä seurannasta saatavat tulokset siis voivat kertoa ja miten hyvin organisaatiot ovat niiden avulla järjesteltävissä avoimen tieteen kypsyydessä suhteessa toisiinsa? Ja toisaalta, jos tarkoituksena onkin kartoittaa kansallinen lähtötilanne tilanteessa, jossa organisaatiot eivät ole vielä lähivuosien toiminnansuunnittelunsa myötä kyenneet toteuttamaan tuoreimpia konkreettisia päämääriä ja esitettyjä toimenpiteitä, kuinka aito kuva lähtötilanteesta saadaan, kun seurantamalli antaa valmiin sapluunan sille, mitä pitäisi edistää ja miten? Lisäksi nyt edetään tutkimusorganisaatioiden seuranta edellä, vaikka niiden toimintaedellytyksiin vaikuttaa suuresti olemassa oleva kansallinen infrastruktuuri ja toimijat kuten CSC (Tieteen tietotekniikan keskus). 
Monet kansalliset kysymyksemme ovat luonteeltaan kansainvälisiä. Avoimen tieteen vastuullisen arvioinnin periaatteita on selvitelty hiljan EOSC Co-Creation -hankkeessa. Tässä yhteydessä selvitettiin, mikä on tutkijoiden arviointiin käytettävien tietojen nykytila suhteessa FAIR-dataan. Selvityksen pohjalta hankkeessa luotiin tulevaisuuden visio FAIR-datan käytöstä tutkijoiden arvioinnissa. (TSV 2021d)

“Avointa tiedettä voidaan rohkaista ja palkita kehittämällä vastuullisempaa tutkijanarviointia, joka huomioi laajasti avoimet tuotokset ja avoimen tieteen aktiviteetit. Vastuullisempi arviointi pohjaa sekä datan hallinnan FAIR-periaatteisiin että tutkimuksen vastuullisen arvioinnin linjauksiin (FAIReR = FAIR + Responsible). Toteutuakseen vastuullisempi arviointi edellyttää lukuisten sidosryhmien (tutkimusyhteisöjen, päättäjien, rahoittajien ja kustantajien) yhteistyötä sosiaalisten ja kulttuurillisten esteiden ja haasteiden työstämiseen. Vastuullisempi arviointi tarvitsee myös avointen tieteen käytäntöjen ja tuotoksen arvioimisen mahdollistavan teknisen infrastruktuurin kehittämistä.” (emt., ks. lähemmin Mustajoki et al. 2021)

Aiempaa vastuullisempi avoimen tieteen seuranta tarvitsee siis tuekseen myös kansallisten avoimen tieteen palveluiden ja infrastruktuurin jatkokehittämistä ja kansainvälisenkin toimintaympäristön kehittämistä ja yhteen nivomista kansallisiin ratkaisuihin ja palveluihin. Ilman sitä eri tieteenalat ja laajemman tutkimustuotos-näkökulman huomioon ottavaa kokonaisarkkitehtuuria ei ole mahdollista arvioida kattavasti ja vertailukelpoisesti avointa tiedettä edistävien tuotosten ja aktiviteettien toteumaa. Tämän vuoksi olisikin nähdäksemme tärkeää, että arvioitavien tahojen seurantajärjestyksessä ensisijainen huomio olisi avoimen tieteen arkkitehtuurin selvittämisessä ja sen varmistamisessa, että kansallisen tason AT-infrastruktuuripuutteet tulevat selkeästi kartoitetuksi, osoitetuksi ja täytetyiksi. Vasta sen jälkeen on mahdollista lähemmin velvoittaa mm. yliopistoja huolehtimaan organisaatiotason AT-toteutumista ja tarkastella vaikka myös niiden mahdollista sisällyttämistä mm. OKM-rahanjakomalliin vertaisarvioitujen julkaisujen (julkaisutyypit A ja C) avoimuuslisäkerrointa laajemmin.

Edellisten seurantojen tapaan organisaatioiden ennakoidaan panostavan siihen, että ne pärjäävät seurannassa (so. vertailussa), eikä sen asettamien vaatimusten ulkopuoliselle kehittämiselle välttämättä jää resursseja. Se, onko seuranta tehokkain keino avoimen tieteen edistämiseen jää nähtäväksi, mutta joka tapauksessa seurannan toteuttaminen vaatii lisäresursseja sekä kansallisella tasolla avoimen tieteen sihteeristöön että organisaatiotasolla tietovarantojen kartuttamiseen sekä kyselyyn vastaamiseen. Lisäksi organisaatioille syntyy vertailun kautta kannustin ohjata voimavarojaan omiin ratkaisuihin, vaikka kenties ennemmin niitä pitäisi ohjata kansalliseen kehittämi- 
seen ja yhteisiin ratkaisuihin. On myös mahdollista, että vertailun aiheuttama kilpailuasetelma organisaatioiden välillä vähentää halukkuutta yhteistyöhön.

Seurantamallia suunnitelleen työryhmän puheenjohtaja, Kalle-Antti Suominen (2021) toteaa 12.10. julkaistussa blogikirjoituksessaan, että seurannan tarkoitus on ennen kaikkea tuottaa tietoa organisaatioille niiden oman toiminnan kehittämiseen. Tästä on helppo olla samaa mieltä, organisaatioiden tulee voida seurata edistymistään, ja siihen malli tarjoaa erinomaisen pontimen. Edellyttääkö se kuitenkaan seikkaperäistä vertailtavuutta? Vaikka seurantamallissa todetaan, että vain samanlaisia organisaatioita voidaan vertailla keskenään, malli tuottaa joka tapauksessa pisteytyksen, joka asettaa organisaatiot järjestykseen suhteessa toisiinsa. Epäselväksi jää, kenen vastuulle jää vastuullinen vertailu, ja mitä itse asiassa tarkoittaa samanlaiset organisaatiot - esimerkiksi yliopistot keskenään, vai kyselyn tulosten perusteella samanlaiset, vai tarjoutuuko meille mahdollisuus tarkastella avoimessa tieteessä kehittymistä myös tieteenalalähtöisesti?

\section{Lähteet}

Agate, N., Kennison, R., Konkiel, S., Long, C. P., Rhody, J., Sacchi, S., \& Weber, P. (2020). The transformative power of values-enacted scholarship. Humanities and Social Sciences Communications, 7(1), 1-12. https://doi.org/10.1057/s41599-020-00647-z

Forsström, P.-L., Lilja, E., \& Alamantila, M. (2020). Atlas of open science and research in Finland 2019 : Evaluation of openness in the activities of higher education institutions, research institutes, research-funding organisations, Finnish academic and cultural institutes abroad and learned societies and academies. Final report. Publications of the Ministry of Education and Culture, Finland 2019:45. http://urn. fi/URN: ISBN: 978-952-263-689-8

Hicks, D., Wouter, P., Waltman, L., de Rijcke, S., \& Rafols, I. (2015). Bibliometrics: The Leiden Manifesto for research metrics. Nature 520, 429-431. https://doi.org/10.1038/520429a

Himanen, L., \& Gadd, E. (2019). Introducing SCOPE - a process for evaluating responsibly. Bibliomagician. https://thebibliomagician.wordpress.com/2019/12/11/introducing-scopeaprocess-for-evaluating-responsibly/

Lahtinen, A. (2021). Avoimuuden väliinputoajat. TJNK-näkökulma. Tiedonjulkistamisen neuvottelukunnan blogi (2.11.2021). https://tjnk.fi/fi/ajankohtaista/tjnk-nakokulma-anulahtinen-avoimuuden-valiinputoajat

Landscape of EOSC-related infrastructures and initiatives (2020). Report from the EOSC executive board working group (WG) landscape : version 2. (19.11.2020). https://doi. org/10. $2777 / 132181$

Lilja, E. (2020). Threat of policy alienation: Exploring the implementation of Open Science policy in research practice. Science and Public Policy, 47(6), 803-817. https://doi.org/10.1093/ scipol/scaa044 
Mustajoki, H., Pölönen, J., Gregory, K., Ivanović, D., Brasse, V., Kesäniemi, J., . . Pylvänäinen, E. (2021). Making FAIReR assessments possible. Final report of EOSC Co-Creation projects: "European overview of career merit systems" and "Vision for research data in research careers". https://doi.org/10.5281/zenodo. 4701375

Opetus- ja kulttuuriministeriö (OKM) (2020). Uutiset, Tutkimusorganisaatiot toimivat aiempaa avoimemmin (10.1.2020). https://minedu.fi/-/tutkimusorganisaatiot-toimivataiempaa-avoimemmin

Pölönen, J., Pylvänäinen, E., Aspara, J., Puuska, H.-M., \& Rinne, R. (2021). Publication Forum 2010-2020: Self-evaluation report of the Finnish quality classification system of peerreviewed publication channels. Web publications of Federation of Finnish Learned Societies, 9. https://doi.org/10.23847/isbn.9789525995442

San Fransisco Declaration on Research Assessment (DORA) (2012). https://sfdora.org/

Suominen, K.-A. (2021). Miten arvioida avoimen tieteen edistymistä? Turun yliopiston blogi (12.10.2021). https://blogit.utu.fi/utu/2021/10/12/miten-arvioida-avoimentieteen-edistymista/

Tieteellisten seurain valtuuskunta (TSV) (2020). Avoin tiede, Ajankohtaista, Avoimen tieteen ja tutkimuksen seuranta uudistuu (18.9.2020). https://avointiede.fi/fi/ajankohtaista/ avoimen-tieteen-ja-tutkimuksen-seuranta-uudistuu

Tieteellisten seurain valtuuskunta (TSV) (2021a). Avoin tiede, Ajankohtaista, Seurantamallin kommentointi alkaa (27.9.2021). https://avointiede.fi/fi/ajankohtaista/ seurantamallin-kommentointi-alkaa

Tieteellisten seurain valtuuskunta (TSV) (2021b). Avoin tiede. Avoimen tieteen seurantamalli. Luonnos. (27.9.2021) https://docs.google.com/document/d/17uTQAGOcEpIQG9UkD75Xu5sif_ CQGXX-bXB9rIsgw-w/edit

Tieteellisten seurain valtuuskunta (2021c). Avoin tiede, Seurannan kyselyn ja sen pisteytyksen luonnos. (27.9.2021) https://docs.google.com/document/d/1fnYfCoWc47Pn61Q2b8qNhMSijXFjoOpBxSphTnS4fRc/edit

Tieteellisten seurain valtuuskunta (TSV) (2021d). Avoin tiede, Ajankohtaista, Vastuullisempi tutkijanarviointi edellyttää läpinäkyvyyttä ja oikeita rakenteita (7.5.2021). https:// avointiede. fi/fi/ajankohtaista/vastuullisempi-tutkijanarviointi-edellyttaalapinakyvyytta-ja-oikeita-rakenteita

UNESCO (2021). UNESCO Recommendation on Open Science. https://unesdoc.unesco.org/ ark:/48223/pf0000379949. locale=en

Wilsdon, J., Allen, L., Belfiore, E., Campbell, P., Curry, S., Hill, S., . . Johnson, B. (2015). The Metric Tide: Final Report with executive summary. HEFCE. https://doi.org/10.13140/ RG.2.1.4929.1363 